\title{
EDITORIAL
}

\section{Escándalos y prácticas no transparentes en Chile: ¿Algo de qué preocuparnos en Radiología?}

En esta época del año, se produce un hecho importante, como es el egreso de los residentes de Radiología en nuestro país desde sus distintos centros formadores. En general, el objetivo de la formación de los becados, se basa en tres enseñanzas fundamentales: saber, saber hacer y saber ser. El saber, implica la adquisición de los conocimientos básicos de las distintas técnicas radiológicas que utilizamos; el saber hacer, implica aprender a realizar los procedimientos radiológicos en particular y la atención directa del paciente que de ellos se desprende; por último el saber ser, implica para los que han estado en entrenamiento el saber cómo comportarse en el diario vivir desde el punto de vista humano, respecto de aptitudes y valores en la práctica diaria de la Radiología.

Es precisamente en los objetivos que implican la ética del saber ser donde ni las universidades ni las sociedades científicas deben desconocer lo que está sucediendo en nuestra sociedad. La Sociedad Chilena de Radiología tiene entre sus objetivos de trabajo, además del desarrollo intelectual con cursos de educación continua y actualización, la actividad gremial ligada a la organización del trabajo médico y un importante rol en los aspectos éticos de nuestra práctica; este último punto algo en deuda.

La Radiología, como otros campos laborales, ofrece sin duda la posibilidad de actuar al margen de lo parece cada vez estar menos establecido. Desde faltas pequeñas, con omisiones sutiles hasta conductas francamente ilegales en hospitales, clínicas y centros médicos; todo cabe también, desafortunadamente, dentro de nuestra especialidad.

Este concepto del trabajo radiológico ético, implica por ejemplo saludar a los pacientes (una de los reclamos más frecuentes) y explicar resultados a pacientes y a clínicos. Implica devolver la confianza entregada en nuestro trabajo dando seguridad a pacientes, familiares y médicos; seguridad de que revisamos antecedentes y exámenes previos, de que elegimos el medio de contraste adecuado, de que minimizamos las dosis de radiación, chequeamos la naturaleza de los dispositivos antes de entrar al resonador, solicitamos apoyo anestésico cuando fue necesario. Implica, por último, el respeto por las capacidades personales y de los otros, cumpliendo con nuestro horario contratado, no haciendo exámenes que no sabemos hacer, no firmando exámenes que no realizamos, no eligiendo exámenes fáciles para dejar a otros aquellos más complejos y largos, no haciendo informes telegráficos que nada aportan y no menospreciando el trabajo de los que atendieron al paciente antes que nosotros.

No se trata de que las personas no conozcan los valores, los conocen, sin embargo, no los ponen en práctica, minimizando su real magnitud cuando nos afectan y afectan a otros. En los últimos años hemos conocido un sinnúmero de casos de prácticas deshonestas en distintas instituciones a lo largo del país, que nos pudieran parecer lejanos a nuestro quehacer. Pero cuántos de nosotros somos tentados diariamente a conseguir ventajas ilegítimas, pequeñas o grandes, habitualmente secretas, contrarias a lo que sería una práctica transparente. Es por esto que los invito a hacerse esta pregunta: frente a los variados casos de corrupción en nuestro país, ¿tenemos también nosotros una crisis de transparencia? Los radiólogos que ahora se incorporan al trabajo deberán decidir todos los días cómo enfrentarán estos y los demás desafíos que imponga su práctica laboral. Reflexionen y cuando tengan dudas de cómo proceder, recuerden que las palabras "imágenes" e "integridad", comienzan con la misma letra.

Dr. Marcelo Gálvez M.

\section{Editor Científico}

Palabras clave: Ética, Integridad, Practica radiológica. 